\title{
Material Balance And Reaction Kinetics Modeling For Penex Isomerization Process In Daura Refinery
}

\author{
Adel Sharif Hamadi ${ }^{1}$ and Rawnak Adnan Kadhim ${ }^{2}$ \\ ${ }^{1}$ University of Technology, Chemical Engineering Department, Baghdad - Iraq \\ ${ }^{2}$ Midland Refineries Company, Daura Refinery, Baghdad - Iraq
}

\begin{abstract}
Penex Deisohexanizer isomerization of light straight run naphtha is a significant process for petroleum refining and proved to be effective technology to produce gasoline components with a high octane number. Modeling of the chemical kinetic reactions is an important tool because it is a better tool for optimization of the experimental data into parameters used for industrial reactors. The present study deals on the isomerization process in Daura refinery. Material balance calculations were done mathematically on the unit for the kinetics prediction purpose. A kinetic mathematical model was derived for the prediction rate constants $\mathrm{K}_{1}$ and $\mathrm{K}_{2}$ and activation energy Ea at operating temperatures range $120-180^{\circ} \mathrm{C}$. According to the model, the results show that with increasing of temperature leads to increased $\mathrm{K}_{1}$ directly, where the $\mathrm{K}_{2}$ values proportional inversely. The activation energy results show that $\mathrm{Ea}_{1_{(\mathrm{nC})}}<\mathrm{Ea}_{1(\mathrm{C} 5)}<\mathrm{Ea}_{1(\mathrm{CH})}$, and for $\mathrm{Ea}_{2(\mathrm{iC})}<\mathrm{Ea}_{2(2,2-\mathrm{DMB})}<\mathrm{Ea}_{2(2,3-\mathrm{DMB})}<\mathrm{Ea}_{2(\mathrm{MCP}) .}$.
\end{abstract}

\section{Introduction}

The Penex Deisohexanizer (DIH) isomerization is a process operated using the catalytic reaction of $\mathrm{n}$ pentanes, n-hexanes, and mixtures thereof to produce isomerate hydrocarbons. The reactions take place in a hydrocatalytic fixed bed reactor to promote conversion and minimize hydrocracking [1]. The process of light naphtha can produce isomerate hydrocarbons with higher octane number, in addition, that the typical Penex unit product can blend into gasoline pool, and the nonconverted low octane components $\left(\mathrm{nC}_{6}, \mathrm{CH}\right.$ and MP's) from the deisohexanizer column (DIH) can be recycled to the reactor section for further upgrading [2].

The major elements of Penex (DIH) isomerization processes are reactors operated using chlorinatedalumina $\left(\mathrm{Pt} / \mathrm{Al}_{2} \mathrm{O}_{3}-\mathrm{Cl}\right)$ as catalyst $[3,4]$. This catalyst is proven to be active at lower temperatures $\left(120-180^{\circ} \mathrm{C}\right)$ in which equilibrium favorable to produce iso-paraffins. [5]. The scheme of Penex (DIH) process is illustrated in Fig. 1. [6]

The most important process variables in Penex isomerization unit are the reactor temperatures. The higher temperatures than equilibrium lead to increase the amount of hydrocracking and increase the carbon formation on the catalyst.

A typical UOP Penex unit is provided with two reactors in series. All of the benzene rings in the LSRN feed are hydrogenated in the first reactor and some conversion of cyclohexane $(\mathrm{CH})$ and methyl cyclopentane (MCP) to hexanes also occurs, as does some hydrocracking of $\mathrm{C}_{7}$ components to $\mathrm{C}_{3}$ and $\mathrm{C}_{4}$.

The hydrogenation of benzene rings, naphthene conversion to hexane, and $\mathrm{C}_{7}$ hydrocracking are exothermic reactions and, for a typical feedstock, contribute more to the temperature rise in the reactor than exothermic reaction of paraffin isomerization.
The concentrations and outlet temperature will be influenced by the catalyst and by the mass of $\mathrm{C}_{6}$ cyclic and $\mathrm{C}_{7}$ components in the feed.

\section{Penex Unit Reaction Mechanism}

\section{$2.1 \mathrm{nC}_{5}$ Reaction Mechanism [7]}

The Isomerization reaction of normal paraffins to isoparaffins is slightly exothermic and thermodynamically favorable at a temperature range $120-180^{\circ} \mathrm{C}$. The kinetics of the reaction proceed in series through an olefin as an intermediate product formed by dehydrogenation of n-paraffins through an adsorption mechanism on the surface of metal site catalyst.

$$
n \text { pentane } \stackrel{p t}{\rightarrow} n \text { pentene }
$$

Because of low equilibrium conversion of paraffin isomerization, n-olefins can be converted to carbonium ion with the aid of injection of strong chloride acid as initiator ion.

$n$ pentene $+\left[\mathrm{H}^{-}\right]\left[\mathrm{A}^{-}\right] \rightarrow$ carbonium ion $+\left[\mathrm{A}^{-}\right]$

This initiator ion allows equilibrium forward to removes n-olefin from the first hydrogenation reaction, and then to rearrange the molecules.

carbonium ion $\rightarrow$ iso pentane carbonium ion

The high catalytic acidity causes a hydrogenation reaction to proceed at a higher reaction rate. Then, the carbonium ion converted iso-paraffin to iso-olefin by dehydrogenation step.

iso pentane carbonium ion $\rightarrow$ iso pentene

In the last reaction, the iso-olefin is hydrogenated again to form iso-paraffin in the presence of surface of the catalyst.

$$
\text { iso pentene } \stackrel{p t}{\rightarrow} \text { iso pentane }
$$




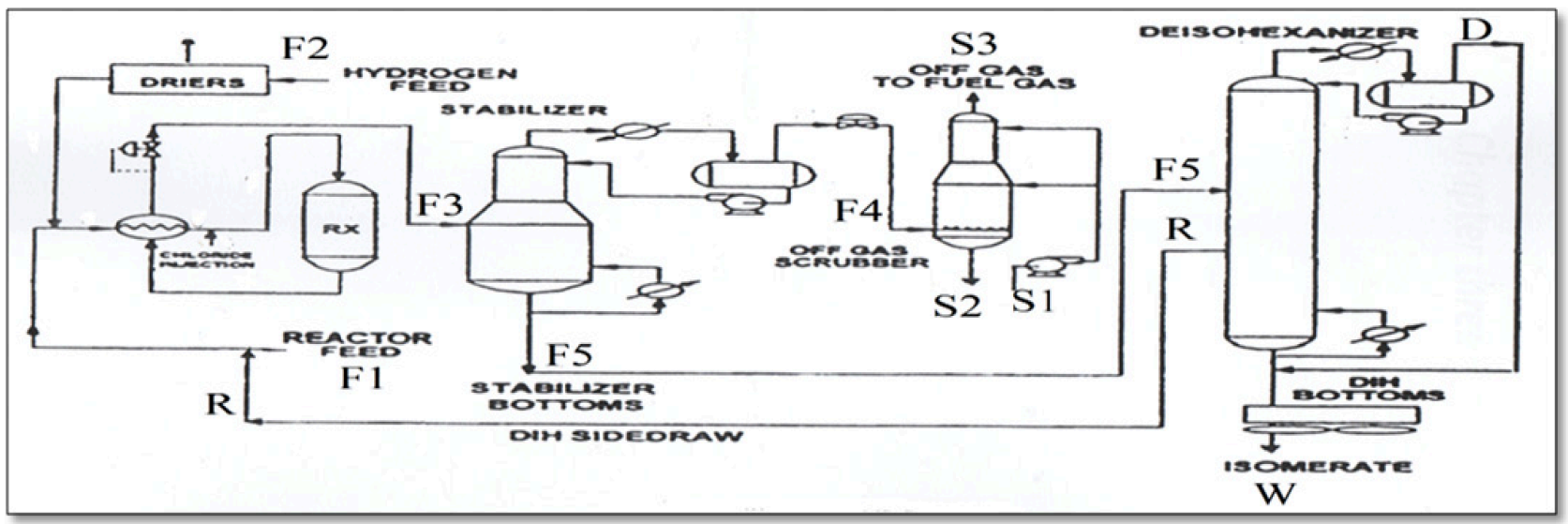

Fig. 1 Block Diagram of Penex (DIH) Isomerization Unit

Generally, the final steps of $\left(n-C_{6}\right)$ isomerization proceed similarly, thus $\left(\mathrm{n}-\mathrm{C}_{6}\right)$ several iso-products like 2-MP, 3-MP, 2,2-DMB, and 2,3-DMB is can be produced.

\section{2 nC6 Reaction Mechanism [8]}

$$
\begin{gathered}
n \text { pentane }_{(R O N=24.8)} \stackrel{p t}{\Leftrightarrow} 2 M P_{(R O N=73.4)} \\
\text { npentane }_{(R O N=24.8)} \stackrel{p t}{\Leftrightarrow} 3 M P_{(R O N=74.5)} \\
n \text { pentane }_{(R O N=24.8)} \stackrel{p t}{\Leftrightarrow} 2,2 D M B_{(R O N=91.8)} \\
n \text { pentane } \\
(R O N=24.8)
\end{gathered}
$$

The relationship between equilibrium conversion vs. isomerization reaction temperatures of $\left(\mathrm{C}_{5}\right.$ and $\left.\mathrm{C}_{6}\right)$ paraffins are shown in Fig. 2 and 3, respectively [5].

\subsection{Other Reactions [9]}

There are several reactions occurring inside and outside of the reactors.

\subsubsection{Inside Reactors:}

a) Naphthene ring of methyl cyclopentane (MCP) and cyclohexane $(\mathrm{CH})$ present in the Penex feed will hydrogenate to n-paraffins, and then to iso-paraffins. The increasing in reactor temperature leads to increase Naphthene ring opening reactions.

b) As the temperature increased, the naphthenes shift forwards to (MCP) production.

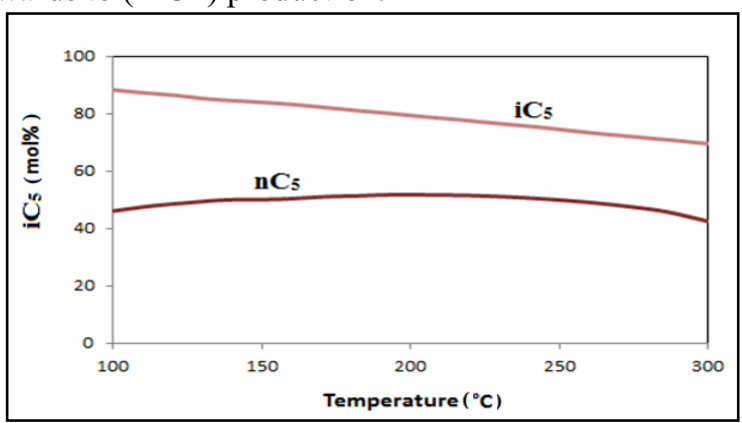

Fig. 2: $\mathrm{C}_{5}$ Paraffin Equilibrium Curves [5].

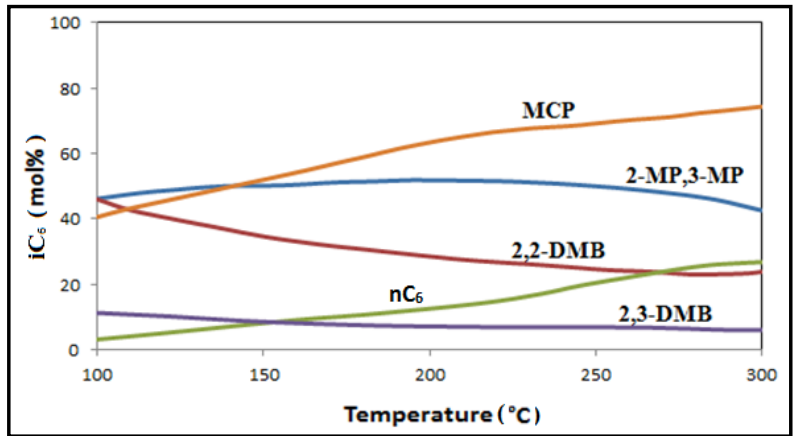

Fig 3: $\mathrm{C}_{6}$ Paraffin Equilibrium Curves [5].

$$
\text { cyclohexane }_{(R O N=84)} \stackrel{p t}{\Leftrightarrow} M C P_{(R O N=104.3)}
$$

c) Very quickly hydrogenation reaction of the benzene ring in the presence of a catalyst $\left(\mathrm{Pt} / \mathrm{Al}_{2} \mathrm{O}_{3}-\mathrm{Cl}\right)$ proceed at very low temperature.

benzene $_{(\mathrm{RON}>100)}+3 \mathrm{H}_{2} \stackrel{p t}{\Leftrightarrow}$ cyclohexane $_{(\mathrm{RON}=84)}$

d) Hydrocracking of Penex feed according to types of feed quality. For example, $\mathrm{C}_{7}$ molecules tend to hydrocrack easily than smaller ones, paraffins of $\mathrm{C}_{5}$ and $\mathrm{C}_{6}$ hydrocrack to some extent. The severity of hydrocracking tends to reduce yield and increase product temperature.

\subsubsection{Outside Reactors :}

a) Hydrogen chloride is injected annually at period of maintenance time, to limit corrosion problems in units, the reaction run until removed any rust present in the unit.

$$
6 \mathrm{HCl}+\mathrm{Fe}_{2} \mathrm{O}_{3} \rightarrow 2 \mathrm{FeCl}_{3}+3 \mathrm{H}_{2} \mathrm{O}
$$

b) Perchloroethylene $\left(\mathrm{C}_{2} \mathrm{Cl}_{4}\right)$ is injected before reactors at approximately the temperature of $\left(110^{\circ} \mathrm{C}\right)$ or higher. The present hydrogen will react with this promoter in the presence of a catalyst $\left(\mathrm{Pt} / \mathrm{Al}_{2} \mathrm{O}_{3}-\mathrm{Cl}\right)$ to produce hydrogen chloride.

$$
\mathrm{C}_{2} \mathrm{Cl}_{4}+5 \mathrm{H}_{2} \stackrel{(\mathrm{Pt} / \mathrm{Al} 2 \mathrm{O} 3-\mathrm{Cl})}{\longrightarrow} 4 \mathrm{HCl}+\mathrm{C}_{2} \mathrm{H}_{6}
$$

c) Neutralization of hydrogen chloride formed in above reaction using caustic soda $(\mathrm{NaOH})$ to form salt and water in the scrubber.

$$
\mathrm{HCl}+\mathrm{NaOH} \rightarrow \mathrm{NaCl}+\mathrm{H}_{2} \mathrm{O}
$$




\section{Material Balance}

As shown by Fig. 1, there are three streams entering to the rector of Penex unit, the feed (LSRN), makeup gas $\left(\mathrm{H}_{2}\right)$ and recycle (from Deisohexanizer) and outlet stream exit as a product from the reactor. The product stream (F3) exits from the reactor, enters to stabilizer column. In this process, overhead light gases $\left(\mathrm{CH}_{4}, \mathrm{C}_{2} \mathrm{H}_{6}\right.$, $\mathrm{C}_{3} \mathrm{H}_{8}$, and $\mathrm{i}-\mathrm{C}_{4} \mathrm{H}_{10}$ ) and some of $\mathrm{nC}_{5}$ and $\mathrm{iC}_{5}$ which is removed and exit from the top of column, in addition to $\mathrm{H}_{2}$ and $\mathrm{HCl}$, which then enter to scrubber.

The outlet product from the top of stabilizer column enters to the scrubber column where $\mathrm{NaOH}$ solution injected into the scrubber. From the bottom of the stabilizer, the product stream contains $\left(\mathrm{nC}_{5}, \mathrm{iC}_{5}, \mathrm{nC}_{6}, 2-\right.$ MP, 3-MP, 2,2-DMB, 2,3-DMB ,MCP and $\mathrm{CH}$ ) which goes to Deisohexanizer (DIH) column. The outlet product from the bottom of stabilizer enters to the DIH column. There are two streams exit from DIH column, top stream (D) and bottom stream (W).

The mass balance calculations on the unit assuming feed rate of Penex unit $=10,000 \mathrm{BPD}$ is presented in Table (1) and (2) respectively.

Table 1: Material Balance Calculations on the Reactor and Stabilizer Unit Assuming Feed Rate $=10,000$ BPD

\begin{tabular}{|c|c|c|c|c|c|c|c|c|c|c|}
\hline & \multirow{2}{*}{ Comp. } & \multirow{2}{*}{ Mwt } & \multirow{2}{*}{$\begin{array}{l}\text { Density } \\
\left(\mathrm{Kg} / \mathrm{m}^{3}\right)\end{array}$} & \multicolumn{4}{|c|}{ Reactor $(\mathrm{kg} / \mathrm{hr})$} & \multicolumn{3}{|c|}{ Stabilizer $(\mathrm{kg} / \mathrm{hr})$} \\
\hline & & & & F1 in & $F 2$ in & $R$ in & F3 out & F3 in & F4 out & F5 out \\
\hline 1 & $\mathrm{nC}_{5}$ & 72 & 626 & 11276,16 & 0 & 199.731 & 5278.9 & 5278.9 & 18.47 & 5260.43 \\
\hline 2 & $\mathrm{iC}_{5}$ & 72 & 616 & 5688.17 & 0 & 135.817 & 12020.96 & 12020.96 & 281.52 & 11739.44 \\
\hline 3 & $\mathrm{nC}_{6}$ & 86 & 655 & 14808.4 & 0 & 17440.5 & 17736.79 & 17736.79 & 0 & 17736.79 \\
\hline 4 & 2-MP & 86 & 653 & 4899.84 & 0 & 24902.4 & 29802.27 & 29802.27 & 0 & 29802.27 \\
\hline 5 & 3-MP & 86 & 664 & 3915.52 & 0 & 21467.1 & 25382.58 & 25382.58 & 0 & 25382.58 \\
\hline 6 & 2,2-DMB & 86 & 674 & 139.37 & 0 & 719.031 & 12145.51 & 12145.51 & 0 & 12145.51 \\
\hline 7 & $2,3-\mathrm{DMB}$ & 86 & 695 & 1572.30 & 0 & 6559.16 & 11356.35 & 11356.35 & 0 & 11356.35 \\
\hline 8 & $\mathrm{MCP}$ & 84 & 749 & 39.199 & 0 & 23.968 & 501.12 & 501.12 & 0 & 501.12 \\
\hline 9 & $\mathrm{BZ}$ & 78 & 876 & 483.451 & 0 & 8444.62 & 0 & 0 & 0 & 0 \\
\hline 100 & $\mathrm{CH}$ & 84 & 778 & 731.71 & 0 & 199.731 & 8738.38 & 8738.38 & 0 & 8738.38 \\
\hline 11 & $\mathrm{H}_{2}$ & 2 & 0.0899 & 0 & 208.52 & 0 & 170.55 & 170.55 & 170.55 & 0 \\
\hline 12 & $\mathrm{CH}_{4}$ & 16 & 0.668 & 0 & 227.39 & 0 & 227.39 & 227.39 & 227.39 & 0 \\
\hline 13 & $\mathrm{C}_{2} \mathrm{H}_{6}$ & 30 & 1.264 & 0 & 343.92 & 0 & 343.92 & 343.92 & 343.92 & 0 \\
\hline 14 & $\mathrm{C}_{3} \mathrm{H}_{8}$ & 44 & 1.882 & 0 & 392.32 & 0 & 392.38 & 392.38 & 392.38 & 0 \\
\hline 15 & $\mathrm{i}-\mathrm{C}_{4}$ & 58 & 2.5326 & 0 & 230.77 & 0 & 230.77 & 230.77 & 230.77 & 0 \\
\hline 16 & $\mathrm{C}_{2} \mathrm{Cl}_{4}$ & 166 & 1622 & 0 & 0 & 0 & 0 & 0 & 0 & 0 \\
\hline 17 & $\mathrm{HCl}$ & 36.5 & 1.63 & 0 & 0 & 0 & 11.43 & 11.43 & 11.43 & 0 \\
\hline 18 & $\mathrm{NaOH}$ & 40 & 2130 & 0 & 0 & 0 & 0 & 0 & 0 & 0 \\
\hline 19 & $\mathrm{NaCl}$ & 58.5 & 2165 & 0 & 0 & 0 & 0 & 0 & 0 & 0 \\
\hline 20 & $\mathrm{H}_{2} \mathrm{O}$ & 18 & 1000 & 0 & 5.15 & 0 & 0 & 0 & 0 & 0 \\
\hline & Total & & & 43554.12 & 1408.07 & 79892.3 & 123838.18 & 123838.18 & 1676.44 & 43554.12 \\
\hline
\end{tabular}

Table 2: Mass Balance Calculations on the Scrubber and Deisohexanizer Unit Assuming Feed Rate $=10,000$ BPD

\begin{tabular}{|c|c|c|c|c|c|c|c|c|c|c|}
\hline & \multirow{2}{*}{ Comp. } & \multirow{2}{*}{ Mwt } & \multirow{2}{*}{$\begin{array}{l}\text { Density } \\
\left(\mathrm{Kg} / \mathrm{m}^{3}\right)\end{array}$} & \multicolumn{3}{|c|}{ Scrubber (kg/hr) } & \multicolumn{4}{|c|}{ Deisohexanizer $(\mathrm{kg} / \mathrm{hr})$} \\
\hline & & & & F4 in & S1 out & S2 out & $F 5$ in & R out & Wout & Dout \\
\hline 1 & $\mathrm{nC}_{5}$ & 72 & 626 & 18.47 & 18.47 & 0 & 5260.43 & 199.731 & 0 & 5060.70 \\
\hline 2 & $\mathrm{iC}_{5}$ & 72 & 616 & 281.52 & 281.52 & 0 & 11739.44 & 135.817 & 0 & 11603.62 \\
\hline 3 & $\mathrm{nC}_{6}$ & 86 & 655 & 0 & 0 & 0 & 17736.79 & 17440.5 & 48.14 & 248.15 \\
\hline 4 & 2-MP & 86 & 653 & 0 & 0 & 0 & 29802.27 & 24902.4 & 6.95 & 4892.92 \\
\hline 5 & 3-MP & 86 & 664 & 0 & 0 & 0 & 25382.58 & 21467.1 & 20.00 & 3895.48 \\
\hline 6 & 2,2-DMB & 86 & 674 & 0 & 0 & 0 & 12145.51 & 719.031 & 0 & 11426.48 \\
\hline 7 & 2,3-DMB & 86 & 695 & 0 & 0 & 0 & 11356.35 & 6559.16 & 1.61 & 4795.58 \\
\hline 8 & MCP & 84 & 749 & 0 & 0 & 0 & 501.12 & 23.968 & 823.67 & 0 \\
\hline 9 & $\mathrm{BZ}$ & 78 & 876 & 0 & 0 & 0 & 0 & 8444.62 & 0 & 0 \\
\hline 100 & $\mathrm{CH}$ & 84 & 778 & 0 & 0 & 0 & 8738.38 & 199.731 & 52.75 & 0 \\
\hline 11 & $\mathrm{H}_{2}$ & 2 & 0.0899 & 170.55 & 170.55 & 0 & 0 & 0 & 0 & 0 \\
\hline 12 & $\mathrm{CH}_{4}$ & 16 & 0.668 & 227.39 & 227.39 & 0 & 0 & 0 & 0 & 0 \\
\hline 13 & $\mathrm{C}_{2} \mathrm{H}_{6}$ & 30 & 1.264 & 343.92 & 343.92 & 0 & 0 & 0 & 0 & 0 \\
\hline 14 & $\mathrm{C}_{3} \mathrm{H}_{8}$ & 44 & 1.882 & 392.38 & 392.38 & 0 & 0 & 0 & 0 & 0 \\
\hline 15 & $\mathrm{i}-\mathrm{C}_{4}$ & 58 & 2.5326 & 230.77 & 230.77 & 0 & 0 & 0 & 0 & 0 \\
\hline 16 & $\mathrm{C}_{2} \mathrm{Cl}_{4}$ & 166 & 1622 & 0 & 0 & 0 & 0 & 0 & 0 & 0 \\
\hline 17 & $\mathrm{HCl}$ & 36.5 & 1.63 & 11.43 & & 0 & 0 & 0 & 0 & 0 \\
\hline 18 & $\mathrm{NaOH}$ & 40 & 2130 & 0 & 0 & 2.5 & 0 & 0 & 0 & 0 \\
\hline 19 & $\mathrm{NaCl}$ & 58.5 & 2165 & 0 & 0 & 18.32 & 0 & 0 & 0 & 0 \\
\hline 20 & $\mathrm{H}_{2} \mathrm{O}$ & 18 & 1000 & 0 & 0 & 140.91 & 0 & 0 & 0 & 0 \\
\hline & Ttotal & & & 1676.44 & 1665 & 161.73 & 43554.12 & 79892.3 & 122662.9 & 42798.85 \\
\hline
\end{tabular}


The concentration of reactants in the isomerization reactions $\left(\mathrm{nC}_{5}, \mathrm{nC}_{6}\right.$ and $\left.\mathrm{CH}\right)$ in the inlet stream to the reactor is calculated from the mass balance, these concentrations are used to calculate $\mathrm{K}_{1}$ (rate constant for the formation of intermediate olefin). The results are shown in Table (3).

Whereas the mole fraction of the produced isomers outlet from reactor $\left(\mathrm{iC}_{5}, 2,2-\mathrm{DMB}\right.$ 2,3-DMB and $\left.\mathrm{MCP}\right)$ are calculated from the mass balance, these mole fractions are used to calculate $\mathrm{K}_{2}$ (rate constant for the formation of isomers).

Table 3 Concentration of Reacted Components.

\begin{tabular}{|l|l|l|l|}
\hline Component & $\begin{array}{l}\mathrm{F}_{\text {Ao }} \\
(\mathbf{K m o l e})\end{array}$ & $\begin{array}{l}\mathbf{V} \\
\left(\mathbf{m}^{3}\right)\end{array}$ & $\begin{array}{l}\mathbf{C}_{\mathrm{Ao}}=\mathrm{F}_{\mathrm{Ao}} / \mathbf{V} \\
\left(\mathbf{K m o l e} / \mathbf{m}^{3}\right)\end{array}$ \\
\hline $\mathrm{nC}_{5}$ & 156.613 & 18.013 & 8.694 \\
\hline $\mathrm{nC}_{6}$ & 172.191 & 22.608 & 7.161 \\
\hline $\mathrm{CH}$ & 104.03 & 11.23 & 9.26 \\
\hline
\end{tabular}

\section{Development Model}

In the typical isomerization process, several reactions are taken place: paraffin isomerization; naphthene hydrogenation; naphthene isomerization, benzene saturation, hydrocracking; and naphthene alkylation. Table (4) list the reactions and equilibrium conversion suggest for isomerization of normal paraffinic components in the feed of Penex process. [10]

$$
n \text { paraffin } \stackrel{K 1}{\rightarrow} \text { Olefin } \stackrel{K 2}{\rightarrow} \text { i paraffin }
$$

The model developed in this study are taken following assumptions: $1^{\text {st }}$ order reactions at steady state, isothermal conditions, gas phase reaction, constant physical properties, and neglected gradient in pressure drop, temperature and concentration respectively.

Mass balance has been developed over the cross section of the segment of the catalyst bed, as illustrated in Fig. 3.

$$
\begin{gathered}
\mathrm{C}_{\text {Ao }}=\mathrm{C}_{\mathrm{A}}+\mathrm{C}_{\mathrm{N}}+\mathrm{C}_{\mathrm{ISO}} \\
\mathrm{C}_{\mathrm{A}}=\mathrm{C}_{\text {Ao }} \exp \left(-\mathrm{K}_{1} \mathrm{t}\right) \\
\mathrm{C}_{\mathrm{N}}=\frac{\mathrm{K}_{1} \mathrm{C}_{\mathrm{Ao}}}{\mathrm{K}_{2}-\mathrm{K}_{1}}\left[\exp \left(-\mathrm{K}_{1} \mathrm{t}\right)-\exp \left(-\mathrm{K}_{2} \mathrm{t}\right)\right] \\
\mathrm{C}_{\text {ISO }}=\mathrm{C}_{\text {Ao }}\left[1-\exp \left(-\mathrm{K}_{1} \mathrm{t}\right)\right. \\
-\frac{\mathrm{K}_{1}}{\mathrm{~K}_{2}-\mathrm{K}_{1}}\left[\exp \left(-\mathrm{K}_{1} \mathrm{t}\right)\right. \\
\left.\left.-\exp \left(-\mathrm{K}_{2} \mathrm{t}\right)\right]\right]
\end{gathered}
$$

Table 4 A Typical Reactions for LSRN Isomerization

\begin{tabular}{|l|l|l|}
\hline Reactions & Conv. \% & Equ. No. \\
\hline $\mathrm{nC}_{5} \Leftrightarrow \mathrm{iC}_{5}$ & 54 & $(1)$ \\
\hline $\mathrm{nC}_{6} \Leftrightarrow 2,2-\mathrm{DMB}$ & 35 & $(2)$ \\
\hline $\mathrm{nC}_{6} \Leftrightarrow 2,3-\mathrm{DMB}$ & 10 & $(3)$ \\
\hline $\mathrm{BZ}+3 \mathrm{H}_{2} \Leftrightarrow \mathrm{CH}$ & 100 & $(4)$ \\
\hline $\mathrm{CH} \Leftrightarrow \mathrm{MCP}$ & 59 & $(5)$ \\
\hline $2-\mathrm{MP} \rightarrow 3-\mathrm{MP}$ & & $(6)$ \\
\hline $3-\mathrm{MP} \rightarrow 2,2-\mathrm{DMB}+2,3-\mathrm{DMB}$ & & $(7)$ \\
\hline
\end{tabular}

The design equation for volume of tubular reactor:

$$
\mathrm{V}=\mathrm{F}_{\mathrm{Ao}} \frac{\int \mathrm{dx}}{-\mathrm{K}_{1} \mathrm{C}_{\mathrm{Ao}}}
$$

And reactant concentration of $\mathrm{C}_{\mathrm{A}}$ in gas phase:

$$
\mathrm{C}_{\mathrm{A}}=\mathrm{C}_{\text {Ao }} \frac{(1-\mathrm{x}) \mathrm{T}_{\mathrm{o}}}{(1-\varepsilon \mathrm{x}) \mathrm{T}}
$$

Where $\varepsilon$ is refer to voidage in reactor bed.

Putting equation (13) into (12) and re-arrange, to get the reaction rate constant $\mathrm{K} 1$ as shown in equation (14). From Arrhenius equation (15), the activation energy $\left(\mathrm{Ea}_{1}\right)$ and frequency factor $\left(\mathrm{K}_{\mathrm{o}}\right)$ can be calculated by plot $\left(\ln \mathrm{K}_{1}\right)$ vs. $(1 / \mathrm{T})$, as illustrated in Fig. 4.

$$
\begin{gathered}
K_{1}=\frac{F_{A o}}{V C_{A o}}\left[\ln \frac{1}{1-x}(1+\varepsilon)-\varepsilon x\right] \frac{T}{T_{o}} \\
\ln K_{1}=\ln K_{o}-\frac{E_{a}}{R T}
\end{gathered}
$$

\section{Results And Discussion}

The model shown by equation (14) can be used to calculate isomerization reaction rate constant $\mathrm{K}_{1}$, using data given from Penex unit in the Daura Refinery: Volume of catalyst in each reactor $=35.66 \mathrm{~m}^{3}$, Hold up $=$ $75 \%, \varepsilon=0.393$, and $\mathrm{T}_{\mathrm{o}}=50^{\circ} \mathrm{C}$.

Table (5) represents the results of $\mathrm{K}_{1}$ at temperatures range of $120-180{ }^{\circ} \mathrm{C}$. It was shown that calculated reaction constants of $\left(\mathrm{K}_{1}\right)$ values increased with increasing temperature and reach maximum value at a temperature $\left(180^{\circ} \mathrm{C}\right)$.

Applying equation $(15)$ and plot $\left(\ln K_{1}\right)$ vs $(1 / T)$ for components listed in Table (6) are shown in Fig. 5.

The activation energy $\left(\mathrm{Ea}_{1}\right)$ and Frequency factor $\left(\mathrm{Ko}_{1}\right)$ are calculated from these plots and tabulated in Table (7). The results show that $\mathrm{Ea}_{1\left(\mathrm{nC}^{*}\right)}<\mathrm{Ea}_{1(\mathrm{nC} 6 * *)}<\mathrm{Ea}_{1(\mathrm{C} 5)}<$

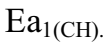

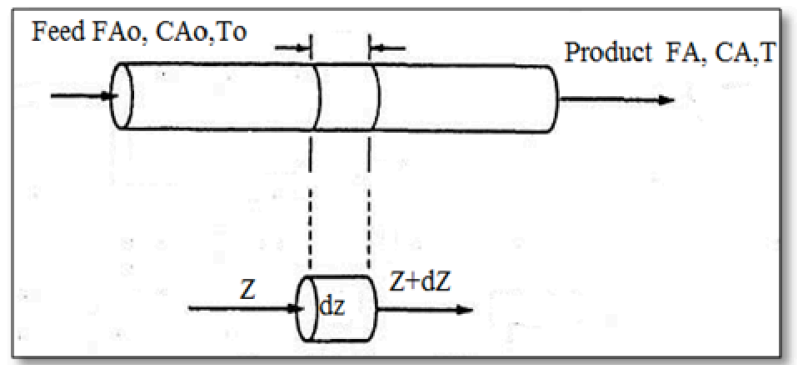

Fig. 3: Segment of Tubular Catalyst Bed Reactor. 


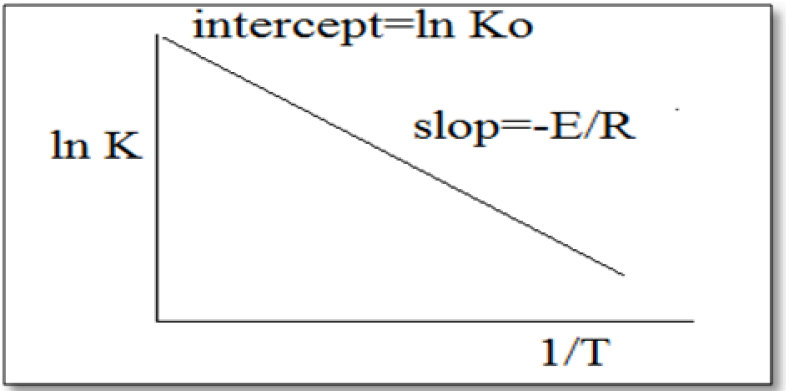

Fig. 4: The Relationship Between $\left(\ln \mathrm{K}_{1}\right)$ vs. $(1 / \mathrm{T})$

Table 5: Results of $\mathrm{K}_{1}$.

\begin{tabular}{|l|l|l|l|l|l|}
\hline \multirow{2}{*}{$\mathrm{T}\left({ }^{\circ} \mathrm{C}\right)$} & \multirow{2}{*}{$\mathrm{T}\left({ }^{\circ} \mathrm{K}\right)$} & \multicolumn{4}{|l|}{$\mathrm{K}_{1}\left(\mathrm{~h}^{-1}\right)$} \\
\cline { 3 - 6 } & & $\boldsymbol{n} \boldsymbol{C}_{5}$ & $\boldsymbol{n} \boldsymbol{C}_{6}{ }^{*}$ & $\boldsymbol{n} \boldsymbol{C}_{6}{ }^{* *}$ & $\boldsymbol{C H}$ \\
\hline 120 & 393 & 0.398 & 0.241 & 0.056 & 0.289 \\
\hline 135 & 408 & 0.413 & 0.250 & 0.058 & 0.300 \\
\hline 150 & 423 & 0.429 & 0.260 & 0.060 & 0.311 \\
\hline 165 & 438 & 0.444 & 0.269 & 0.062 & 0.322 \\
\hline 180 & 453 & 0.459 & 0.278 & 0.065 & 0.333 \\
\hline
\end{tabular}

Where $n C_{6}{ }^{*}$ for $n C_{6} \leftrightarrow 2,2-D M B$ at $x=0.35$, and $n C_{6} * *$ for $n C_{6} \leftrightarrow 2,3-D M B$ at $x=0.1$

Table 6: $\ln K_{1}$ and 1/T Values.

\begin{tabular}{|l|l|l|l|l|}
\hline \multirow{2}{*}{$1 / \mathrm{T}$} & \multicolumn{1}{|l|}{$\ln \mathrm{K}_{1}$} & \multicolumn{4}{|l|}{} \\
\cline { 2 - 5 } & $\boldsymbol{n} \boldsymbol{C}_{5}$ & $\boldsymbol{n} \boldsymbol{C}_{6}{ }^{*}$ & $\boldsymbol{n} \boldsymbol{C}_{6} \boldsymbol{*}^{*}$ & $\boldsymbol{C H}$ \\
\hline 0.0025 & -0.9202 & -1.4164 & -2.8759 & -1.2429 \\
\hline 0.0025 & -0.8828 & -1.3789 & -2.8385 & -1.2055 \\
\hline 0.0024 & -0.8467 & -1.3428 & -2.8024 & -1.1694 \\
\hline 0.0023 & -0.8118 & -1.3080 & -2.7675 & -1.1345 \\
\hline
\end{tabular}

Equation (11) can be used to calculate the rate constant $\mathrm{K}_{2}$ for reaction on olefin to iso-paraffin. The required data were taken from Daura Refinery; as LHSV $=1.5$, residence time $\mathrm{t}=1 / \mathrm{LHSV}=0.667 \mathrm{~h}$. The values of $\mathrm{K}_{2}$ are shown in Table (8), which was shown that $\mathrm{K}_{2}$ values decreasing with increasing temperature, which means that product isomerate concentrations were increased as a result of temperature sensitivity of isomerization reactions.

Applying equation (15) and plot $\left(\ln _{2}\right)$ vs $(1 / T)$ for components listed in Table (9) are shown in Fig. 6.

The values of the activation energy $\left(\mathrm{Ea}_{2}\right)$ and Frequency factor $\left(\mathrm{Ko}_{2}\right)$ are calculated from these plots and tabulated in Table (10). The results show $\mathrm{Ea}_{2}(\mathrm{iC} 5)<\mathrm{Ea}_{2(2,2-\mathrm{DMB})}<$ $\mathrm{Ea}_{2(2,3-\mathrm{DMB})}<\mathrm{Ea}_{2(\mathrm{MCP})}$.

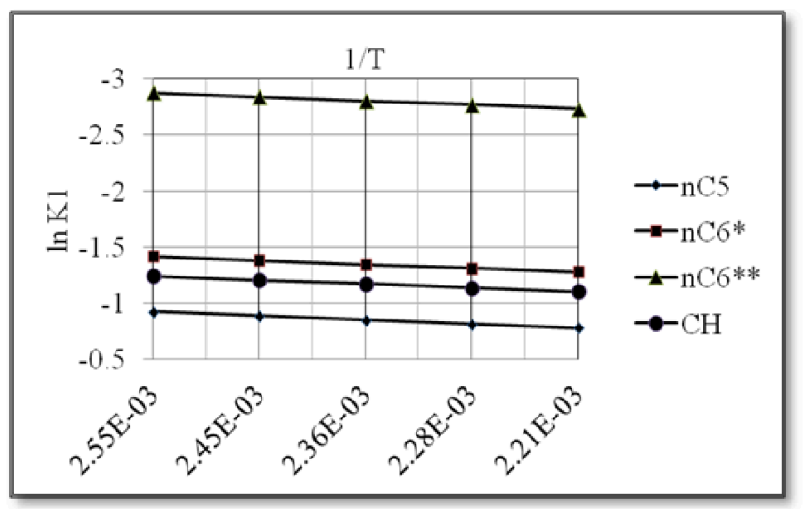

Fig. 5: Plot $\left(\ln \mathrm{K}_{1}\right)$ vs. $(1 / \mathrm{T})$
Table 7: Activation Energy and $\mathrm{Ko}_{1}$ Results.

\begin{tabular}{|l|l|l|}
\hline Component & $\mathrm{Ea}_{1}(\mathrm{KJ} / \mathrm{mole})$ & $\mathrm{Ko}_{1}$ \\
\hline $\mathrm{nC}_{5}$ & 2738.822 & 0.460 \\
\hline $\mathrm{nC}_{6}{ }^{*}$ & 1525.743 & 0.263 \\
\hline $\mathrm{nC}_{6}{ }^{* *}$ & 1835.182 & 0.061 \\
\hline $\mathrm{CH}$ & 2880.394 & 0.334 \\
\hline
\end{tabular}

Table 8: Results of $\mathrm{K}_{2}$.

\begin{tabular}{|c|c|c|c|c|c|}
\hline \multirow[b]{2}{*}{$\mathrm{T}\left({ }^{\circ} \mathrm{C}\right)$} & \multirow[b]{2}{*}{$\mathrm{T}(\mathrm{K})$} & \multicolumn{4}{|l|}{$\mathrm{K}_{2}\left(\mathrm{~h}^{-1}\right)$} \\
\hline & & $i C_{5}$ & $\begin{array}{l}2,2- \\
D M B\end{array}$ & $\begin{array}{l}2,3- \\
D M B\end{array}$ & $M C P$ \\
\hline 120 & 393 & 0.1547 & 0.2566 & 1.2062 & 0.0147 \\
\hline 135 & 408 & 0.1480 & 0.2477 & 1.1512 & 0.0124 \\
\hline 150 & 423 & 0.1430 & 0.2389 & 1.0998 & 0.0113 \\
\hline 165 & 438 & 0.1384 & 0.2308 & 1.0529 & 0.0099 \\
\hline 180 & 453 & 0.1346 & 0.2232 & 1.0099 & 0.0097 \\
\hline
\end{tabular}

Table 9: $\ln K_{2}$ and 1/T Values

\begin{tabular}{|l|l|l|l|l|}
\hline \multirow{2}{*}{$1 / \mathrm{T}$} & \multicolumn{4}{|l|}{$\ln \mathrm{K}_{2}$} \\
\cline { 2 - 5 } & $\mathbf{i} \boldsymbol{C}_{5}$ & 2,2-DMB & 2,3-DMB & $\boldsymbol{M C P}$ \\
\hline 0.0025 & -0.8106 & -0.5907 & 0.0814 & -1.8327 \\
\hline 0.0025 & -0.8298 & -0.6062 & 0.0612 & -1.9066 \\
\hline 0.0024 & -0.8446 & -0.6218 & 0.0413 & -1.9469 \\
\hline 0.0023 & -0.8588 & -0.6368 & 0.0224 & -2.0044 \\
\hline 0.0022 & -0.8711 & -0.6513 & 0.0043 & -2.0132 \\
\hline
\end{tabular}

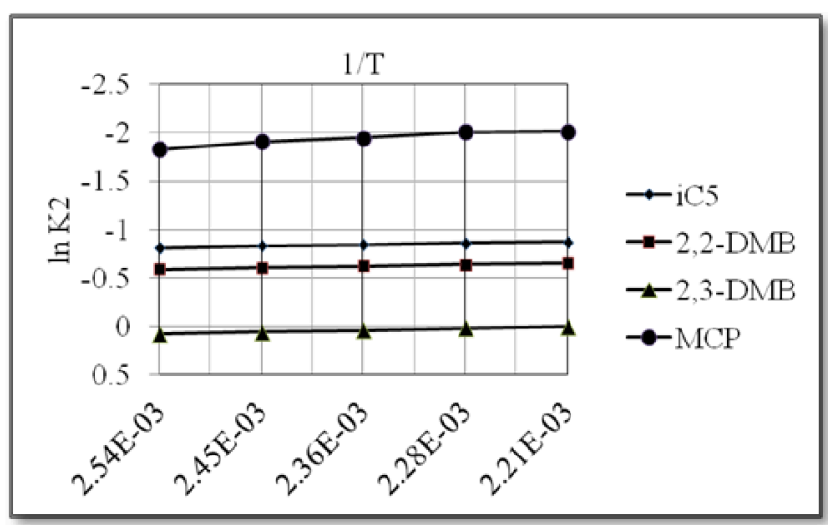

Fig. 6: Plot $\left(\ln \mathrm{K}_{2}\right)$ vs. (1/T)

Table 10: Activation Energy and $\mathrm{Ko}_{2}$ Results.

\begin{tabular}{|l|l|l|}
\hline Component & $\mathrm{Ea}_{2}(\mathrm{KJ} / \mathrm{mole})$ & $\mathrm{Ko}_{2}$ \\
\hline $\mathrm{iC}_{5}$ & 1.503 & 0.281 \\
\hline $2,2-\mathrm{DMB}$ & 1.519 & 0.349 \\
\hline $2,3-\mathrm{DMB}$ & 1.931 & 0.602 \\
\hline $\mathrm{MCP}$ & 4.632 & 0.038 \\
\hline
\end{tabular}

\section{Conclusions}


1. The increasing temperature leads to increased $\mathrm{K}_{1}$ according to reactor model (proportional directly).

2. The $\mathrm{K}_{2}$ values decreased when the temperature increased for the isomerate (proportional inversely) which indicates the increasing in the isomerate concentration.

3. The activation energy results show that $\mathrm{Ea}_{1(\mathrm{nC} 6)}<\mathrm{Ea}_{1(\mathrm{C} 5)}<\mathrm{Ea}_{1(\mathrm{CH})}$, and for $\mathrm{Ea}_{2}{ }_{(\mathrm{iC} 5)^{<}}$ $\mathrm{Ea}_{2(2,2-\mathrm{DMB})}<\mathrm{Ea}_{2(2,3-\mathrm{DMB})}<\mathrm{Ea}_{\text {2(MCP) }}$, which means the reaction of lower activation energy have higher reaction rate.

\section{Abbreviations}

\begin{tabular}{|c|c|}
\hline $\mathrm{dz}$ & Integration Step for the Reactor Length \\
\hline $\begin{array}{l}2,2- \\
\mathrm{DMB}\end{array}$ & 2,2-Dimethylbutane \\
\hline $\begin{array}{l}2,3- \\
\text { DMB }\end{array}$ & 2,3-Dimethylbutane \\
\hline 2-MP & 2-Methylpentane \\
\hline 3-MP & 3-Methylpentane \\
\hline $\mathrm{BZ}$ & Benzene \\
\hline $\mathrm{nC}_{6} *$ & $\begin{array}{l}\text { Concentration for } \mathrm{nC}_{6} \leftrightarrow 2,2-\mathrm{DMB} \text { at } \\
\mathrm{x}=0.35 \text {, }\end{array}$ \\
\hline $\mathrm{nC}_{6} * *$ & $\begin{array}{l}\text { Concentration for } \mathrm{nC}_{6} \leftrightarrow 2,3-\mathrm{DMB} \text { at } \\
\mathrm{x}=0.1\end{array}$ \\
\hline $\mathrm{CA}$ & $\begin{array}{l}\text { Concentration of } n \text {-paraffin present at } \\
\text { time } t\end{array}$ \\
\hline CAo & $\begin{array}{l}\text { Concentration of inlet LSRN stream } \\
\left(\mathrm{mole} / \mathrm{m}^{3}\right)\end{array}$ \\
\hline Ciso & Concentration of i-paraffin. \\
\hline $\mathrm{CN}$ & Concentration of $n$-olefin \\
\hline $\mathrm{CH}$ & Cyclohexane \\
\hline $\mathrm{D}$ & Top stream of DIH shown in Fig. 1 \\
\hline $\mathrm{DIH}$ & Deisohexanizer (DIH) \\
\hline $\mathrm{Ea}_{1}$ & $\begin{array}{llll}\text { Activation } & \text { energy } & \text { for } & \mathrm{n} \text { paraffin } \\
\mathrm{K} 1 & & & \\
\rightarrow \text { Olefin } & & & \\
\end{array}$ \\
\hline $\mathrm{Ea}_{2}$ & Activation energy for Olefin $\stackrel{\mathrm{K} 2}{\rightarrow} \mathrm{i}$ paraffin \\
\hline F1 & Reactor feed shown in Fig. 1 \\
\hline $\mathrm{F} 2$ & Hydrogen feed shown in Fig. 1 \\
\hline F3 & Stabilizer feed shown in Fig. 1 \\
\hline $\mathrm{F} 4$ & Scrubber feed shown in Fig. 1 \\
\hline F5 & DIH feed shown in Fig. 1 \\
\hline FAo & Mole rate of inlet component LSRN \\
\hline Fiso & Mole rate of isomerate product \\
\hline $\mathrm{HC}$ & Hydrocarbon \\
\hline $\mathrm{i}-\mathrm{C}_{4}$ & Iso-butane \\
\hline $\mathrm{iC}_{5}$ & Iso-pentane \\
\hline $\mathrm{iC}_{6}$ & iso-hexane \\
\hline K1 & Rate Constant for Paraffins (hr-1) \\
\hline $\mathrm{K} 2$ & Rrate Constant for Olefins (hr-1) \\
\hline Ko & Frequency Factor \\
\hline LHSV & Liquid Hourly Space Velocity \\
\hline LSRN & Light straight run naphtha \\
\hline MCP & Methyl cyclopentane \\
\hline $\mathrm{nC}_{5}$ & Normal pentane \\
\hline $\mathrm{nC}_{6}$ & Normal hexane \\
\hline $\mathrm{Pt}$ & Platinum \\
\hline $\mathrm{Pt} / \mathrm{ZrO}_{2-}$ & Sulfated zirconia \\
\hline
\end{tabular}

\begin{tabular}{|l|l|}
\hline $\mathrm{SO}_{4}$ & \\
\hline $\mathrm{Pt} / \mathrm{Al}_{2} \mathrm{O}_{3}-$ & Chlorinated alumina \\
$\mathrm{Cl}$ & \\
\hline $\mathbf{R}$ & DIH sidedraw shown in Fig. 1 \\
\hline $\mathrm{R}$ & Gas Constant (8.314 J/K.. mole) \\
\hline $\mathrm{RON}$ & Research Octane Number \\
\hline $\mathrm{t}$ & Residence time (hr) \\
\hline $\mathrm{S} 1$ & $\begin{array}{l}\text { NaOH solution feed to scrubber shown in } \\
\text { Fig. 1 }\end{array}$ \\
\hline $\mathrm{S} 2$ & Bottom of scrubber shown in Fig. 1 \\
\hline $\mathrm{S} 3$ & $\begin{array}{l}\text { Off gas outlet from the scrubber shown in } \\
\text { Fig. 1 }\end{array}$ \\
\hline $\mathrm{T}$ & Temperature (K) \\
\hline $\mathrm{To}$ & Initial temperature $(\mathrm{K})$ \\
\hline $\mathrm{V}$ & Volume of reactor (m $\left.{ }^{3}\right)$ \\
\hline $\mathrm{W}$ & Bottom stream of DIH shown in Fig. 1 \\
\hline $\mathrm{x}$ & reaction conversion \\
\hline $\mathrm{Zt}$ & Length of reactor $(\mathrm{Cm})$ \\
\hline$\varepsilon$ & Voidage \\
\hline
\end{tabular}

\section{References}

[1]. H. Weyda and E. Koehler, "Modern Refining Concepts - an Update on Naphtha-Isomerization to Modern Gasoline Manufacture". Catalyst Today, 81, (2003).

[2]. Hallo., J. Hancsok and D. Kallo, "Kinetics of hydroisomerization of $\mathrm{C} 5-\mathrm{C} 7$ alkanes and their mixtures over platinum containing mordenite". Applied Catalyst. A:General, 229, 93, (2002).

[3]. W. McCabe, J. Smith, and P. Harriott, "Unit Operations of Chemical Engineering", $7^{\text {th }}$ ed.. McGraw Hill., (2004).

[4]. G. Valavarasua and B. Sairamb "Light Naphtha Isomerization Process: A Review". Petroleum Science and Technology, 31, 6, (2013).

[5]. Z. Rui, M. Xianghai, L. Zhichang, M. Jiaying and X. Chunming, "Isomerization of n-Pentane Catalyzed by Acidic Chloroaluminate Ionic Liquids". Industrial and Engineering Chemistry Research, 47, 21, pp 8205-8210, (2008).

[6]. T. Bui., V. Nguyen and A. Akhmetov, "A Comparative Analysis of the Various Schemes Isomerization of Pentane-Hexane Fraction". Refining and Petrochemicals, 2, pp.22-25, (2008).

[7]. Cusher N., UOP Penex Process in: R. A. Mayers, Handbook of petroleum refining processes, McGraw-Hill, 9.16-9.27, (2004).

[8]. Elena, E. Alexander, S. Shilov,V. Dmitrievich and Z. Gennady, "Chemical And Biological Kinetics New Horizons: Vol. 1, Chemical Kinetics 1st Edition", 1991.

[9]. G. James, "The Chemistry and Technology of Petroleum", 4th ed. CRC Press, 2006.

[10]. M. Marios, G. Denis,G. Pierre, and S. Daniel," Single-Event Microkinetic Model for Long-Chain Paraffin Hydrocracking and Hydroisomerization on an Amorphous Pt/SiOR2R AlR2ROR3R Catalyst", India Engineering Chemical Research, 48, pp. 3284 3292, (2009). 